\title{
Determination of Science Teacher Candidates' Approaches to the Concept of Chemistry with Metaphors
}

Manuscript ID:

EDU-2021-09044024

Volume: 9

Issue: 4

Month: September

Year: 2021

P-ISSN: 2320-2653

E-ISSN: 2582-1334

Received: 10.05.2021

Accepted: 24.07.2021

Published: 01.09.2021

Citation:

Yadigaroğlu, Mustafa.

"Determination of Science

Teacher Candidates'

Approaches to the

Concept of Chemistry

with Metaphors." Shanlax

International Journal of

Education, vol. 9, no. 4,

2021, pp. 13-23.

DOI:

https://doi.org/10.34293/

education.v9i4.4024

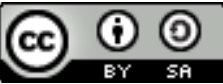

This work is licensed under a Creative Commons Attribution-ShareAlike 4.0 International License

\author{
Mustafa Yadigaroğlu \\ Aksaray University, Turkey \\ iD https://orcid.org/0000-0001-8143-2339
}

\begin{abstract}
The role of science teachers in the formation of students' approaches to chemistry subjects is very important. Metaphors can be used as a data collection tool to determine what meanings science teachers, who are preparing to step into the teaching profession, attribute to some concepts. It is important to know how chemistry is perceived by science teacher candidates and what meanings they attribute to this concept. With this in mind, the aim of the study is to determine the science teacher candidates' approaches to the concept of chemistry through metaphors. Participants of the study are 104 teacher candidates attending the science teaching program of the mathematics and science education department of a medium-sized education faculty in Central Anatolia. A qualitative research method was used in the study, and "Phenomenology" was chosen as the design of the research. As the data collection tool, a form consisting of 1 question was used for the specified concept. The obtained data were analyzed with content analysis technique. The correctness of the determined metaphors and the created categories were checked by two expert faculty members, and the metaphors and categories were finalized. As a result of the analysis, it was determined that the teacher candidates produced 47 metaphors for the concept of chemistry. It is seen that among the metaphors produced by science teacher candidates, the most used ones are life, water, and kitchen. The researcher states that the data collected through metaphors can be supported with different data collection tools, and more in-depth information can be reached.
\end{abstract}

Keywords: Science teacher candidate, Metaphor, Chemistry

\section{Introduction}

The word metaphor is derived from the Greek word "Metapherein" and is formed by combining the words Meta (to change) and pherein (to carry) (Levine, 2005). Metaphors help us learn new information by explaining objects we cannot express with familiar objects (Perry \& Cooper, 2001). When the literature is examined, it is possible to come across metaphor definitions made by different researchers. For example; According to Palmquist (2001), metaphor; is a metaphorical structure created as a result of establishing a relationship between two concepts or objects by comparing existing similarities and differences. According to Guerrero and Villamil (2002), metaphor; They are tool used to explain the complex structures of any area and to provide information so that it can be understood easily. Metaphor is the indirect expression of a concept, situation, or object with the help of another concept or object, not directly with itself (Deant-Reed \& Szokolszky, 1993). Briefly, metaphor can be expressed as explaining something with another term (Marshall, 2010). Metaphors can be used in educational studies to visualize, depict and explain an abstract concept (Singh, 2010).

Individuals can perceive the events and concepts that occur in their environment differently. For this reason, the concepts used to better explain a defined concept may differ according to the person (Eryllmaz Toksoy \& Akdeniz, 2020). This difference can be explained better with the help of 
metaphors. When individuals use metaphors, they combine their imaginations and experiences (Demirtaş \& Çoban, 2014). In cases where individuals cannot make adequate explanations with the help of known words, they reflect their feelings and thoughts belonging to their inner worlds with the help of metaphors (Leavy et al., 2007). Metaphors contribute to determining how concepts are perceived. When studies in the field of education are examined, it is found that metaphors are frequently used to determine perceptions about a particular phenomenon (Inbar, 1996; Guerrero \& Villamil, 2002; Lakoff \& Johnson, 2003). The metaphor technique is a technique that determines what is actually what is meant to be explained using few words in the studies and facilitates translating abstract concepts into concrete (Demirbilek, 2021). Metaphors are used as tools that facilitate the understanding of abstract expressions and enrich the educational environment rather than being a standalone teaching method. Because it can be used to explain abstract expressions, metaphors can be used to examine individuals' perceptions of various concepts (Büyükekşi et al., 2018). As metaphors, it is stated that it can be used as a data collection tool in studies to describe the existing state of a situation, phenomenon, or event. (Morgan, 1980).

Chemistry is an important branch of science. Chemistry studies the structure of matter, its properties, and interactions with each other (Hançer et al., 2007). Chemistry, which is an indispensable discipline in all areas of life, is closely related to our daily life (Cetinkaya \& Ayartepe, 2020; Heng \& Karpudewan, 2015). Although chemistry is an important part of daily life, it contains many basic concepts that require more abstract and more mental thinking (Zoller, 1990). Students have trouble concretizing many chemistry concepts in their minds. Therefore, it is seen as a discipline difficult to understand (Kee \& McGovan, 1998; Reid, 2000; Koçak, 2011). This situation causes students to have difficulties in learning chemistry subjects and in considering chemistry lesson as difficult. Since it contains many abstract concepts and is seen as a difficult lesson, learners can explain chemistry with the help of metaphors (Thomas \& McRobbie, 1999; Jeppsson et al., 2013).
Metaphors are powerful tools for generating new ideas (Yildizlı et al., 2018). This situation reveals why metaphors are important in scientific development (D'Hanis, 2002). When metaphor studies about education are examined; It is seen that many studies have been carried out on many concepts and that metaphors are emphasized. Since the thought becomes clearer through metaphor, metaphors are used in educational studies (Y1ldizlı et al., 2018).

Although studies aimed at revealing metaphorical perceptions about different phenomena in educational research have increased remarkably in recent years, metaphor studies on the concept of chemistry (Thomas \& McRobbie, 1999; Jeppsson et al., 2013; Derman, 2014; Büyükekşi et al., 2018; Özkurt Sivrikaya, 2019) and the studies conducted to determine the metaphorical perceptions of science teacher candidates towards the concept of chemistry (Anılan, 2017; Önen Öztürk \& Ağlarc1, 2017) were found to be limited in number. Anılan (2017), classified 98 metaphors developed by teacher candidates for the concept of chemistry in 21 different categories in the study, which aimed to reveal the metaphorical perceptions of the science teacher candidates who will teach the concept of chemistry, and which 177 science teacher candidates participated. The most frequently developed metaphors by teacher candidates for the concept of chemistry were life, water, life, riddle-puzzle, need, and love. It has been revealed that the meanings that the teacher candidates attribute to the concept of chemistry are generally positive. When Önen Öztürk and Ağlarcı (2017) evaluated the opinions of the chemistry and science teacher candidates at different grade levels on the field of chemistry and how the studies in the field of chemistry were carried out and the findings obtained in their study aimed at examining the metaphors about chemistry according to class level and field, it shows that both chemistry and science teacher candidates' metaphors for the concept of chemistry are similar.

The research can be considered as an effort to fill this gap in the literature. In addition, teacher candidates, who will be responsible for teaching basic chemistry concepts, will give clues about the chemistry teaching environments that they will 
shape in the future. One of the main aims of teacher education studies is to examine the perceptions, attitudes and beliefs of teacher candidates and to contribute to their professional development by determining their tendencies (Noyes, 2004). With the metaphor technique used in this study, it was tried to determine how teacher candidates perceive the concept of chemistry and how it can transform it from abstract to concrete, how they conceptualize the concept of chemistry and what they liken it to. For this reason, it is thought that the study can provide important information about how the concept of chemistry is understood by science teacher candidates and how it is filled. One of the most effective ways to determine science teacher candidates' approaches to the concept of "chemistry" is to use metaphors. In this context, the study aims to reveal the perceptions of science teacher candidates towards chemistry through metaphors.

\section{Method}

\section{Research Pattern}

This study aimed to reveal the metaphorical perceptions of science teacher candidates towards the concept of chemistry; therefore, the phenomenology (phenomenology) design, one of the qualitative research models, was used. The phenomenological pattern focuses on phenomena for which we do not have an in-depth and detailed understanding. Cases; events, experiences, perceptions, orientations, concepts, and situations can appear in our daily lives in various ways (Annells, 2006; Creswell, 2013; Yıldırım \& Şimşek, 2011). In phenomenological studies, it is aimed to reveal and interpret individual perceptions of a phenomenon in general (Y1ldirım \& Şimşek, 2011). In this direction, the perceptions of science teacher candidates about the concept of chemistry were revealed and interpreted.

\section{Working Group}

The study group of research consists of the teacher candidates attending the Science Education Program of Aksaray University, Faculty of Education, Dept. of Mathematics \& Science Education in the spring semester of the 2017-2018 academic year. The grade levels of the participants and the number of participants at each grade level are shown in Table 1.
Table 1: Grade Level and Number of Participants

\begin{tabular}{|c|c|c|}
\hline \multirow{2}{*}{ Grade Level } & \multicolumn{2}{|c|}{ Gender } \\
\cline { 2 - 3 } & Male & Female \\
\hline 1st Class & 5 & 18 \\
\hline 2nd Class & 2 & 34 \\
\hline 3rd Class & 11 & 27 \\
\hline 4th Class & 4 & 3 \\
\hline Total & 22 & 82 \\
\hline
\end{tabular}

As seen in Table 1, 23 (5 males, 18 females) attending the first grade, 36 students in the second grade (2 males, 34 females), 38 (11 males, 27 females) in the third grade, 47 (4 males, three females) attending the class and a total of 104 (22 males, 82 females) teacher candidates attended. Participants were coded as "P1 ...... P104 (Participant 1 ......., Participant 104)".

\section{Data Collection}

In the study, a form consisting of 1 open-ended question was used to determine the metaphorical perceptions of science teacher candidates towards the specified concept as a data collection tool. In the form of the teacher, candidates were asked to complete the statement: "Chemistry is like................. because ................." The teacher candidates were asked to correlate between the metaphor source and the metaphor subject they formed with the expression "like," and they were asked to state a justification for the metaphors they formed with the phrase "because".

In the study, it was checked with the pilot study whether the form prepared for collecting data works by its purpose, and how long the participants formed metaphors. The form developed at the original application stage was applied to the participants by the researcher. The researcher gave some information to the participants about how to create metaphors and what to pay attention to while creating metaphors. Afterward, the participants were given 30 minutes to fill out the form.

\section{Data Analysis}

The data obtained from the answers given by the teacher candidates to the question in the form were analyzed by content analysis. The main purpose 
of using content analysis is to reach concepts and relationships that will help explain the data obtained. In this study, the literature was used to determine the steps to be followed in analyzing metaphors (Anılan, 2017).

Coding and sorting: At this stage, the answers of the participants were examined first. It was coded and numbered in the range $\mathrm{P} 1$...... P104 (Participant 1 ......, Participant 104). The metaphors created by the participants are listed in alphabetical order. A relational category frame was created with the help of the data obtained.

Category development: Among the metaphors listed in alphabetical order, those found to have common features were gathered under the same group, and themes or categories were determined due to the content analysis. While determining the categories, if the metaphors are under the same theme, attention has been paid to the metaphors to forming a meaningful whole. One hundred four participants who participated in the study produced 47 metaphors related to the concept of chemistry. It was determined that some metaphors produced were produced by more than one participant. Nine different categories were created considering the reasons of the participants.

Validity and reliability: To enable the participants to reflect their thoughts, no examples were given and guided by the researcher during the data collection process. By directly including the metaphors and justifications produced by the participants, the results were interpreted in this way.

To ensure the reliability of the research between the coders, opinions were taken from two experts who had studied on qualitative research. Experts were asked to match the metaphors with the categories. Inter-coder reliability was calculated by using the reliability formula $\mathrm{P}$ (Percentage of Agreement $)=\mathrm{Na}$ (Consensus) $/ \mathrm{Na}$ (Consensus) $+\mathrm{Nd}$ (Disagreement) x 100 suggested by Miles and Huberman (1994). It was determined that the agreement between the evaluations of the experts and the researcher was $96 \%$. When the literature is examined, it is stated that to ensure reliability in qualitative research, the harmony between the researcher and the expert should be $80 \%$ and above (Creswell, 2013). In another study, it is stated that the agreement between the researcher and the expert is $90 \%$ and above (Saban, 2009). Since the value calculated in the study was above .90 , it was accepted that the desired reliability was provided.

Care was taken to research within the framework of ethical rules. In this context, the participants were informed about the research, personal information of the participants was not included, and voluntary participation was achieved in the study. It was stated to the participants that the data obtained from the research will only be used for scientific purposes.

Interpretation of the data: The metaphors, categories, and explanations created after realizing these steps mentioned above were presented in figures and tables and explained and interpreted.

\section{Findings}

In this section, the metaphors created by the participants for the concept of chemistry and the categories created with the help of these metaphors are included in tables. Afterward, quotations from the expressions of the participants were included, and the metaphors produced were evaluated.

\section{Metaphors and Categories Generated by Participants Regarding the Concept of Chemistry}

As seen in Figure 1, the metaphors produced by the participants for the concept of chemistry were presented in word cloud form, taking into account the usage intensity.

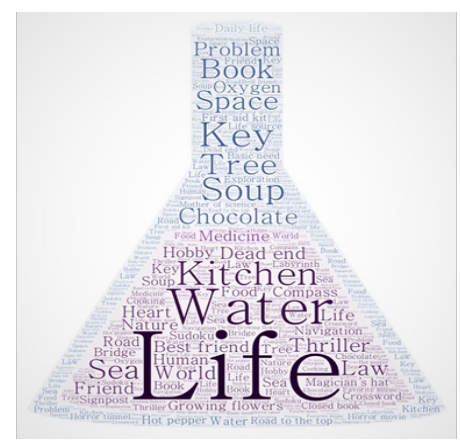

Figure 1: Metaphors produced by the Participants

It was determined that the 47 metaphors produced by the participants for the concept of chemistry were collected in 9 different categories depending on their common characteristics and reasons for use. These categories are given in Figure 2. 


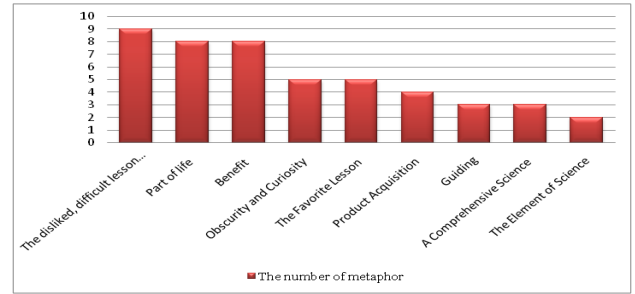

Figure 2: Created categories related to the concept of Chemistry

A total of 47 metaphors produced by the participants for the concept of chemistry were collected in 9 categories. The metaphors produced were listed under the title of the category they belong to and made into tables. Excerpts from the expressions of the participants are directly included in the tables.

Table 2: The Disliked, Difficult Lesson Category

\begin{tabular}{|l|c|l|}
\hline $\begin{array}{c}\text { Name of } \\
\text { Metaphor }\end{array}$ & $\begin{array}{c}\text { Frequency } \\
\text { of use (f) }\end{array}$ & \multicolumn{1}{|c|}{ Quotation } \\
\hline Thriller & 5 & $\begin{array}{l}\text { Chemistry is like a thriller } \\
\text { movie because you don't } \\
\text { like it, but you have to } \\
\text { watch it (P41). }\end{array}$ \\
\hline Problem & 4 & $\begin{array}{l}\text { Chemistry is a problem } \\
\text { because it is a difficult and } \\
\text { disliked lesson (P85). }\end{array}$ \\
\hline Dead end & 4 & $\begin{array}{l}\text { Chemistry is like a dead } \\
\text { end because no matter how } \\
\text { hard you try, you cannot } \\
\text { pass the lesson (P5). }\end{array}$ \\
\hline $\begin{array}{l}\text { Road to } \\
\text { the top }\end{array}$ & 1 & $\begin{array}{l}\text { Chemistry is like the road } \\
\text { to the top because it is } \\
\text { tough (P98). }\end{array}$ \\
\hline Horror \\
movie
\end{tabular}

\begin{tabular}{|l|l|l|}
\hline Crossword & 1 & $\begin{array}{l}\text { Chemistry is like a puzzle } \\
\text { because it is very difficult } \\
\text { to understand the chemistry } \\
\text { lesson (P28). }\end{array}$ \\
\hline Hot pepper & 1 & $\begin{array}{l}\text { Chemistry is like chili } \\
\text { pepper because if you don't } \\
\text { study, you will fail and } \\
\text { suffer (P12) }\end{array}$ \\
\hline
\end{tabular}

There are nine metaphors in the difficult lesson category. When the expressions of the participants are examined, it is stated that the chemistry lesson is difficult and disliked. It is seen that the thriller movie metaphor is used too much in this category.

Table 3: Part of Life Category

\begin{tabular}{|l|c|l|}
\hline $\begin{array}{c}\text { Name of } \\
\text { Metaphor }\end{array}$ & $\begin{array}{c}\text { Frequency } \\
\text { of use (f) }\end{array}$ & \multicolumn{1}{|c|}{ Quotation } \\
\hline Life & 22 & $\begin{array}{l}\text { Chemistry is like life } \\
\text { because it is in everything in } \\
\text { life (P63). }\end{array}$ \\
\hline Water & 10 & $\begin{array}{l}\text { Chemistry is like water } \\
\text { because we need chemistry } \\
\text { all the time (P83) }\end{array}$ \\
\hline Key & 4 & $\begin{array}{l}\text { Chemistry is like a key } \\
\text { because it helps open every } \\
\text { door in our lives (P37). }\end{array}$ \\
\hline Oxygen & 2 & $\begin{array}{l}\text { Chemistry is like oxygen } \\
\text { because we need it all the } \\
\text { time (P49). }\end{array}$ \\
\hline $\begin{array}{l}\text { Life } \\
\text { source }\end{array}$ & 1 & $\begin{array}{l}\text { Chemistry is like a source } \\
\text { of life because it is life itself } \\
\text { (P26). }\end{array}$ \\
\hline Daily life & 1 & $\begin{array}{l}\text { Chemistry is like daily life } \\
\text { because everything we use } \\
\text { contains chemistry (P100). }\end{array}$ \\
\hline Basic need & 1 & $\begin{array}{l}\text { Chemistry is a basic need } \\
\text { because even if it's little } \\
\text { we need the knowledge of } \\
\text { chemistry (P24). }\end{array}$ \\
\hline Human & 1 & $\begin{array}{l}\text { Chemistry is like a human } \\
\text { because it is alive (P78). }\end{array}$ \\
\hline
\end{tabular}

There are eight metaphors in the part of life category. When the expressions of the participants are examined, it is stated that chemistry is a part of our lives. It is seen that the metaphor of life is used the most in this category. 


\begin{tabular}{|c|c|c|}
\hline \multicolumn{3}{|c|}{ Table 4: Benefit Category } \\
\hline $\begin{array}{c}\text { Name of } \\
\text { Metaphor }\end{array}$ & $\begin{array}{c}\text { Frequency } \\
\text { of use (f) }\end{array}$ & Quotation \\
\hline Book & 5 & $\begin{array}{l}\text { Chemistry is like a book } \\
\text { because as you learn, you } \\
\text { feel that you have learned } \\
\text { useful information (P29) }\end{array}$ \\
\hline Tree & 2 & $\begin{array}{l}\text { Chemistry is like trees } \\
\text { because it provides oxygen } \\
\text { for other sciences ( } \mathrm{P} 90) \text {. }\end{array}$ \\
\hline Medicine & 2 & $\begin{array}{l}\text { Chemistry is like medicine } \\
\text { because it allows us to solve } \\
\text { problems thanks to what we } \\
\text { have learned (P86) }\end{array}$ \\
\hline $\begin{array}{l}\text { First aid } \\
\text { kit }\end{array}$ & 1 & $\begin{array}{l}\text { Chemistry is like a first aid } \\
\text { kit because we can solve } \\
\text { the problem in difficult } \\
\text { situations with chemistry } \\
\text { knowledge (P77). }\end{array}$ \\
\hline Law & 1 & $\begin{array}{l}\text { Chemistry is like law } \\
\text { because it makes our life } \\
\text { easier (P61) }\end{array}$ \\
\hline Road & 1 & $\begin{array}{l}\text { Chemistry is like the road } \\
\text { because it leads us to the } \\
\text { solution of the problems we } \\
\text { may encounter in life (P53). }\end{array}$ \\
\hline Food & 1 & $\begin{array}{l}\text { Chemistry is like food } \\
\text { because it is not consumed } \\
\text { all the time, but provides } \\
\text { benefits when consumed } \\
\text { (P43). }\end{array}$ \\
\hline Bridge & 1 & $\begin{array}{l}\text { Chemistry is like a bridge } \\
\text { because it helps to solve } \\
\text { the problems we face in our } \\
\text { daily life (P98) }\end{array}$ \\
\hline
\end{tabular}

There are eight metaphors in the benefits category. When the expressions of the participants are examined, it is stated that chemistry is a useful science. It is seen that the book metaphor is used the most in this category.
Table 5: Obscurity and Curiosity Category

\begin{tabular}{|l|c|l|}
\hline $\begin{array}{c}\text { Name of } \\
\text { Metaphor }\end{array}$ & $\begin{array}{c}\text { Frequency } \\
\text { of use (f) }\end{array}$ & \multicolumn{1}{|c|}{ Quotation } \\
\hline $\begin{array}{l}\text { Magician's } \\
\text { hat }\end{array}$ & 3 & $\begin{array}{l}\text { Chemistry is like a } \\
\text { magician's hat because it is } \\
\text { not known what will come } \\
\text { out of the magician's hat, } \\
\text { and you wonder what you } \\
\text { will learn in the content of } \\
\text { the chemistry lesson (P9) }\end{array}$ \\
\hline Space & 3 & $\begin{array}{l}\text { Chemistry is like space } \\
\text { because the subject } \\
\text { area is very wide so, it } \\
\text { is not possible to know } \\
\text { everything about chemistry } \\
\text { (P82) }\end{array}$ \\
\hline Exploration & 1 & $\begin{array}{l}\text { Chemistry is like } \\
\text { exploration because you } \\
\text { always have the opportunity } \\
\text { to learn something new, } \\
\text { and it is intriguing (P2). }\end{array}$ \\
\hline Llosed & 1 & $\begin{array}{l}\text { Chemistry is like a } \\
\text { labyrinth because when } \\
\text { you start learning the } \\
\text { subjects, you wonder if you } \\
\text { are going to pass the lesson } \\
\text { (P50). }\end{array}$ \\
\hline book & $\begin{array}{l}\text { Chemistry is like a closed } \\
\text { book because you don't } \\
\text { know what will happen in } \\
\text { the lesson (P91). }\end{array}$ \\
\hline
\end{tabular}

There are five metaphors in the category of obscurity and curiosity. When the expressions of the participants are examined, it is stated that the subjects in the chemistry lesson content arouse curiosity and create a feeling of obscurity. It is seen that the magician's hat and space metaphors are used the most in this category.

Table 6: The Favorite Lesson Category

\begin{tabular}{|c|c|l|}
\hline $\begin{array}{c}\text { Name of } \\
\text { Metaphor }\end{array}$ & $\begin{array}{c}\text { Frequency } \\
\text { of use (f) }\end{array}$ & \multicolumn{1}{c|}{ Quotation } \\
\hline Best friend & 2 & $\begin{array}{l}\text { Chemistry is like a best } \\
\text { friend because you feel } \\
\text { close to it, you love it (P32) }\end{array}$ \\
\hline
\end{tabular}




\begin{tabular}{|l|c|l|}
\hline Chocolate & 5 & $\begin{array}{l}\text { Chemistry is like chocolate } \\
\text { because someone who } \\
\text { loves chocolate cannot } \\
\text { give up chocolate just } \\
\text { like people who love } \\
\text { chemistry, you can't give } \\
\text { up on it (P71). }\end{array}$ \\
\hline Friend & 2 & $\begin{array}{l}\text { Chemistry is like a friend } \\
\text { because you cannot give } \\
\text { up your chemistry lesson, } \\
\text { it is with you every day } \\
\text { (P46). }\end{array}$ \\
\hline Hobby & 1 & $\begin{array}{l}\text { Chemistry is like a hobby } \\
\text { because dealing with it will } \\
\text { give you great pleasure } \\
\text { (P76). }\end{array}$ \\
\hline Favorite \\
music & 1 & $\begin{array}{l}\text { Chemistry is like favorite } \\
\text { music, you become happy } \\
\text { when you hear something } \\
\text { about it (P55). }\end{array}$ \\
\hline
\end{tabular}

There are five metaphors in the popular lesson category. When the expressions of the participants are examined, it is stated that the chemistry lesson is a favorite lesson. It is seen that the chocolate metaphor is used the most in this category.

Table 7: Product Acquisition Category

\begin{tabular}{|l|c|l|}
\hline $\begin{array}{c}\text { Name of } \\
\text { Metaphor }\end{array}$ & $\begin{array}{c}\text { Frequency } \\
\text { of use (f) }\end{array}$ & \multicolumn{1}{c|}{ Quotation } \\
\hline Kitchen & 8 & $\begin{array}{l}\text { Chemistry is like a kitchen, } \\
\text { you learn how to easily } \\
\text { produce new products with } \\
\text { the materials you have (P21) }\end{array}$ \\
\hline Soup & 5 & $\begin{array}{l}\text { Chemistry is like soup } \\
\text { because you can use many } \\
\text { different ingredients to } \\
\text { create a new product that } \\
\text { is very different from the } \\
\text { ingredients you have (P10). }\end{array}$ \\
\hline $\begin{array}{l}\text { Growing } \\
\text { flowers }\end{array}$ & 3 & $\begin{array}{l}\text { Chemistry is like growing } \\
\text { flowers because water, seeds } \\
\text { and favorable conditions } \\
\text { create something else. Just } \\
\text { like chemistry (P86). }\end{array}$ \\
\hline
\end{tabular}

\begin{tabular}{|l|l|l|}
\hline Cooking & 1 & $\begin{array}{l}\text { Chemistry is like cooking } \\
\text { because you will definitely } \\
\text { get something at the end } \\
\text { (P2). }\end{array}$ \\
\hline
\end{tabular}

There are four metaphors in the product acquisition category. When the expressions of the participants are examined, it is stated that new products can be obtained with chemistry knowledge. It is seen that the kitchen metaphor is used the most in this category.

\section{Table 8: Guiding Category}

\begin{tabular}{|l|c|l|}
\hline $\begin{array}{c}\text { Name of } \\
\text { Metaphor }\end{array}$ & $\begin{array}{c}\text { Frequency } \\
\text { of use (f) }\end{array}$ & \multicolumn{1}{|c|}{ Quotation } \\
\hline Compass & 2 & $\begin{array}{l}\text { Chemistry is like a compass } \\
\text { because human beings try } \\
\text { to understand themselves } \\
\text { through chemistry (P6) }\end{array}$ \\
\hline Navigation & 2 & $\begin{array}{l}\text { Chemistry is like } \\
\text { navigation because if you } \\
\text { follow it you will not leave } \\
\text { directly, you will explore } \\
\text { the world (P96) }\end{array}$ \\
\hline Signpost & 1 & $\begin{array}{l}\text { Chemistry is like a } \\
\text { guide because it guides } \\
\text { us to understand our } \\
\text { environment (P19) }\end{array}$ \\
\hline
\end{tabular}

There are three metaphors in the guiding category. When the expressions of the participants are examined, it is stated that chemistry is a guiding science for human beings. It is seen that compass and navigation metaphors are used the most in this category.

Table 9: A Comprehensive Science Category

\begin{tabular}{|l|c|l|}
\hline $\begin{array}{c}\text { Name of } \\
\text { Metaphor }\end{array}$ & $\begin{array}{c}\text { Frequency } \\
\text { of use (f) }\end{array}$ & \multicolumn{1}{c|}{ Quotation } \\
\hline Sea & 1 & $\begin{array}{l}\text { Chemistry is like the sea } \\
\text { because it contains a lot of } \\
\text { information that needs to be } \\
\text { learned (P88) }\end{array}$ \\
\hline Nature & 1 & $\begin{array}{l}\text { Chemistry is like nature } \\
\text { because its subjects are } \\
\text { quite comprehensive (P99) }\end{array}$ \\
\hline
\end{tabular}




\begin{tabular}{|l|l|l|}
\hline World & 1 & $\begin{array}{l}\text { Chemistry is like the } \\
\text { world because it has } \\
\text { comprehensive topics (P75). }\end{array}$ \\
\hline
\end{tabular}

There are three metaphors in a comprehensive science category. When the statements of the participants are examined, it is stated that the chemistry topics are quite comprehensive. It is seen that sea, nature, and world metaphors are used in this category.

Table 10: The Element of Science

\begin{tabular}{|l|c|l|}
\hline $\begin{array}{c}\text { Name of } \\
\text { Metaphor }\end{array}$ & $\begin{array}{c}\text { Frequency } \\
\text { of use (f) }\end{array}$ & \multicolumn{1}{|c|}{ Quotation } \\
\hline $\begin{array}{l}\text { Mother of } \\
\text { science }\end{array}$ & 1 & $\begin{array}{l}\text { Chemistry is the mother } \\
\text { of science because } \\
\text { every science has taken } \\
\text { something from chemistry } \\
(\mathrm{P} 45) .\end{array}$ \\
\hline Heart & 1 & $\begin{array}{l}\text { Chemistry is like the } \\
\text { heart because without } \\
\text { chemistry, other sciences } \\
\text { do not have much of a } \\
\text { chance to survive (P21). }\end{array}$ \\
\hline
\end{tabular}

There are two metaphors in the element of science. When the expressions of the participants are examined, it is stated that chemistry is very important for other sciences. It is seen that the metaphors of the mother of science and the heart are used in this category.

\section{Discussion, Conclusion}

Considering that metaphors are the most powerful mental tools used in understanding and explaining an abstract or complex phenomenon, this study aims to reveal the approaches of science teacher candidates to chemistry through metaphors. Nine different conceptual categories were created considering the common features and reasons for using the metaphors created by the teacher candidates. The fact that 104 teacher candidates who participated in the study used 47 different metaphors for chemistry shows the diversity of teacher candidates. Teacher candidates create new perceptions of events and facts by combining their prior knowledge from primary school to university with the new knowledge, experiences, and observations they have acquired during their education years (Beck \& Kosnik, 2006). Teacher candidates develop various attitudes towards the teaching profession with the help of these perceptions (Çıngıl Barış, 2020). In this context, the perceptions acquired by teacher candidates can help us to determine how they will transfer the concepts they will teach to their students when they start their profession and to determine their attitudes and perspectives (Çıngıl Barış, 2020). When the obtained findings were examined, the perceptions of the science teacher candidates about chemistry were examined through metaphors and within the framework of conceptual categories representing these metaphors. Participants used 47 different metaphors to express the concept of chemistry. This situation indicates the diversity of the participants' interests and perspectives towards this concept and that the concept of chemistry cannot be explained with the help of a metaphor alone. When the literature is examined, it is seen that Anılan reported a similar result in his study conducted with 177 teacher candidates in (2017).

One of the most striking results obtained in this study, whose general purpose is to determine the metaphors of science teachers about the concept of "chemistry," is that the category of "disliked, difficult course" is represented with more metaphors than other categories. One of the most important reasons for this situation can be said to be because chemistry contains a large number of concepts that require abstract and high-level thinking skills. When the literature is examined, it is stated that chemistry is a difficult area for students to learn and teachers to teach (Demircioğlu et al., 2012) and includes many abstract concepts (Zoller, 1990, Reidd, 2000). It is thought that another factor that is effective in the teacher candidates' perception of chemistry lessons as "disliked, the difficult lesson" is the continuation of teacher-centered teaching approach since elementary school when chemistry subjects started. When the literature is examined, there are studies reporting that teachers prefer teacher-centered methods more frequently during chemistry teaching (Özden, 2007). To change this perception of students, it is thought that it is necessary to expand the use of alternative methods in the classroom and to create learning environments in a way that takes students' prior 
knowledge into account. While alternative methods are applied in the classroom; It should be kept in mind that the preferred method will not be effective in every subject and for every student (Eryılmaz Toksoy \& Akdeniz, 2020), and attention should be paid to providing learning support in a way that takes students' prior knowledge into account (Lin $\&$ Singh, 2015). One of the reasons why teacher candidates consider chemistry lessons as a difficult lesson that is disliked and show a negative approach to the concept of chemistry is that the content of the chemistry lesson is being taught to them without being associated with daily life. When the literature is examined, it is stated that the majority of students approach chemistry lessons more positively, according to the results of the research on how the approach to the lesson has changed by integrating daily life into chemistry lessons (Wanjek, 2000). Considering that students are first introduced to chemistry subjects through their science teaching, science teachers have important responsibilities. The reason for this is that the personal characteristics of the teachers are seen as an important factor in the fact that chemistry subjects are liked by the students, as well as the subjects being explained about daily life (Gräber, 1992).

Teacher candidates produced many metaphors in the "part of life" and "benefit" categories, which are seen as important from the results obtained based on the answers given. The metaphors of life and water in the category of a part of life are the most frequently used metaphors compared to other metaphors. This situation can be accepted as an indication that teacher candidates see chemistry as related to daily life. Chemistry is an important science closely related to daily life and is widely used in all areas of daily life (Yadigaroğlu et al., 2017). Many events and situations that we encounter, observe, and use in daily life are directly or indirectly related to chemistry (Coştu et al., 2007). Teacher candidates' generating metaphors explaining their view of chemistry as a part of our lives and a beneficial science is important in training teachers with general culture.

As a result, it is possible to contribute to teacher candidates' sociating their identities with their future teacher identities through metaphors (Anılan, 2017). Since metaphors explain something with another term (Marshall, 2010), it can be expected that teacher candidates will use their characteristics and different forms of expression to develop new understandings and concepts. Metaphors are known to be important tools that stimulate the imagination and enable them to establish new contexts (Hanson, 1993). Chemistry concepts; Due to their abstract structure, they're becoming concrete and increasing their comprehensibility depends on their frequent use in daily life. It should not be forgotten that metaphors will be an important tool in the realization of this situation.

\section{Suggestion}

Chemistry lessons conducted in the science teaching program of education faculties are mainly included in the 1 st and 2nd-grade programs. When Table 1 is examined, it is seen that the study was carried out with teacher candidates studying at different grade levels. Considering that memory and attention factors are important factor in forming metaphors (Thibodeau et al., 2017), it may be possible to reach different results in studies that can be planned in the long term. As Türkan and Uyar (2016) stated in their studies, more in-depth information can be accessed by supporting the data collected through metaphors and interviews. Other researchers can carry out a similar study using different research methods in different education levels, different universities, and faculties. In addition to making the participants understand the concept of chemistry, they can conduct studies in which attitudes and success towards chemistry are also discussed. The relationships between them can be investigated.

\section{References}

Annells, Merilyn. "Triangulation of Qualitative Approaches: Hermeneutical Phenomenology and Grounded Theory." Journal of Advanced Nursing, vol. 56 no. 1, 2006, pp. 55-61.

Anılan, Burcu. "Preservice Science Teachers Metaphoric Perceptions about Chemistry Concept." Journal of Qualitative Research in Education, vol. 5, no. 2, 2017, pp. 6-27.

Ateş, Murat, and Akif Karatepe. "The Analysis of University Students' Perceptions towards 
"Environment" Concept with the Help of Metaphors." Journal of Academic Social Science Studies, vol. 6, no. 2, 2013.

Beck, Clive, and Clare Kosnik. Innovations in Teacher Education: A Social Constructivist Approach, SUNY Press, 2006.

Büyükekşi, Cem, et al. “İlköğretim Öğrencilerinin Kimya Algılarının Metaforlar Aracılığıyla Incelenmesi." Karaelmas Eğitim Bilimleri Dergisi, vol. 6, no. 2, 2018, pp. 269-276.

Çetinkaya, Ertan, and Selda Ayartepe. "Examining the Attitudes of High-School Students towards the Chemistry Course Based on Various Variables." Mehmet Akif Ersoy Eğitim Fakültesi Dergisi, 2020, pp. 92-120.

Çıngıl Barış, Çiğdem. "The Metaphoric Perceptions of Pre-Service Science Teachers to the Concept of Biology Laboratory." Journal of Higher Education and Science, vol. 10, no. 3, 2020, pp. 615-624.

Coştu, Bayram, et al. "The Use of Daily-Life Events in Science Teaching." Kırşsehir Eğitim Fakültesi Dergisi, vol. 8, 2007, pp. 197-207.

Creswell, John W. Nitel Araştırma Yöntemler: Beş Yaklaşıma Göre Nitel Araştırma ve Araştırma Deseni. Siyasal Kitabevi, 2013.

Creswell, John W. Qualitative Inquiry \& Resaerch Design: Choosing among Five Approaches. Sage, 2013.

Deant-Read, Cathy H., and Agnes Szokolszky. "Where do metaphors come from?" Metaphor and Symbolic Activity, vol. 8, no. 3, 1993.

de Guerrero, Maria C.M., and Olga S. Villamil. "Metaphorical Conceptualizations of ESL Teaching and Learning." Language Teaching Research, vol. 6, no. 2, 2002, pp. 95-120.

Demirbilek, Nesip. "Metaphoric Perceptions of University Students on Distance Education." E-Uluslararası Ĕ̈itim Araştırmaları Dergisi, vol. 12, no. 1, 2021, pp. 1-15.

Demirtaş, Hasan, and Duygu Çoban. "Metaphors of the college students about Instructors." Kastamonu Ĕgitim Dergisi, vol. 22, 2014.

Derman, Ayşegül. "High School Students' Metaphoric Perceptions for the Concept of Chemistry." Turkish Studies - International Periodical for the Languages, Literature and
History of Turkish or Turkic, vol. 9, 2014.

D'Hanis, I. "A Logical Approach to the Analysis of Metaphors." Logical and Computational Aspects of Model-Based Reasoning, edited by Lorenzo Magnani, et al., Springer, 2002.

Eryılmaz Toksoy, Seyhan, and Ali Riza Akdeniz. "Determination of Preservice Science Teachers' Approaches Related with Physics and Physics Problem via Metaphors." Hacettepe University Journal of Education, vol. 35, no. 3, 2020, pp. 688-703.

Gräber, W. "Interesse am Unterrichtsfach Chemie, an Inhalten und Tätigkeiten." Chemie in der Schule, vol. 39, no. 10, 1992, pp. 354-358.

Hanson, Luett. "Affective Response to Learning via Visual Metaphor." 1993.

Hançer, Ahmet Hakan, et al. "The Evaluation of the Attitudes of Science Teacher Candidates towards Chemistry Lesson." Hacettepe Üniversitesi Eğitim Fakültesi Dergisi, vol. 32, 2007, pp. 100-109.

Heng, Chua Kah, and Mageswary Karpudewan. "The Interaction Effects of Gender and Grade Level on Secondary School Students' Attitude towards Learning Chemistry." Eurasia Journal of Mathematics, Science \& Technology Education, vol. 11, no. 4, 2015, pp. 889-898.

Inbar, Dan E. "The Free Educational Prison: Metaphors and Images." Educational Research, vol. 38, no. 1, 1996, pp. 77-92.

Jeppsson, Fredrik, et al. "Exploring the Use of Conceptual Metaphors in Solving Problems on Entropy." Journal of the Learning Sciences, vol. 22, no. 1, 2013, pp. 70-120.

Lakoff, George, and Mark Johson. Metaphors We Live By. University of Chicago Press, 2003.

Leavy, Aisling M., et al. "An Examination of What Metaphor Construction reveals about the Evolution of Preservice Teachers' Beliefs about Teaching and Learning." Teaching and Teacher Education, vol. 23, no. 7, 2007.

Levine, Phoebe M. "Metaphors and Images of Classrooms." Kappa Delta Pi Record, vol. 41, no. 4, 2005, pp. 172-175.

Lin, Shih-Yin, and Chandralekha Singh. "Effect of Scaffolding on Helping Introductory Physics 
vol. 2, no. 2, 2004, pp. 131-155.

Students Solve Quantitative Problems Involving Strong Alternative Conceptions." Physical Review Special Topics - Physics Education Research, vol. 11, no. 2, 2015.

Marshall, Julia. "Five Ways to Integrate: Using Strategies from Contemporary Art." Art Education, vol. 63, no. 3, 2010, pp. 13-19.

Miles, Matthew B., and Michael A. Huberman. Qualitative Data Analysis: An Expanded Sourcebook. Sage Publications, 1994.

Morgan, Gareth. "Paradigms, Metaphors, and Puzzle Solving in Organization Theory." Administrative Science Quarterly, vol. 25, no. 4, 1980, pp. 605-622.

Noyes, Andrew. "(Re)Producing Mathematics Educators: A Sociological Perspective." Teaching Education, vol. 15, no. 3, 2004.

Önen Özturk, Fatma, and Oya Ağlarc1. "Prospective Chemistry and Science Teachers' Views and Metaphors about Chemistry and Chemical Studies." Eurasian Journal of Educational Research, no. 71, 2017, pp. 119-140.

Özden, Mustafa. "Qualitative and Quantitative Evaluation of Chemistry Teachers' Problems Encountered during Chemistry Teaching: Samples of Adiyaman and Malatya." Pamukkale Üniversitesi Eğitim Fakültesi Dergisi, 2007, pp. 40-53.

Özkurt Sivrikaya, Serpil. "Chemistry with Metaphors: Case of Kocaeli (Turkey) Vocational School." European Journal of Education Studies, vol. 6, no. 6, 2019, pp. 25-37.

Palmquist, Ruth A. "Cognitive Style and Users' Metaphors for the Web: An Exploratory Study." The Journal of Academic Librarianship, vol. 27, no. 1, 2001, pp. 24-32.

Perry, Chris, and Maxine Cooper. "Metaphors are Good Mirrors: Reflecting on Change for Teacher Educators." Reflective Practice, vol. 2, no. 1, 2001, pp. 41-52.

Saban, Ahmet. "Entry Level Prospective Classroom Teachers' Metaphors about the Concept of Teacher." Türk Eğitim Bilimleri Dergisi,
Saban, Ahmet. "Metaphors about School." Educational Administration: Theory and Practice, vol. 55, 2008, pp. 459-496.

Saban, Ahmet. "Prospective Teachers' Mental Images about the Concept of Student." Türk Eğitim Bilimleri Dergisi, vol. 7, no. 2, 2009, pp. 281-326.

Singh, Kathryn. "Metaphor as a Tool in Educational Leadership Classrooms." Management in Education, vol. 24, no. 3, 2010, pp. 127-131.

Thibodeau, Paul H., et al. "How Linguistic Metaphor Scaffolds Reasoning." Trends in Cognitive Sciences, vol. 21, no. 11, 2017, pp. 852-863.

Thomas, Gregory P., and Campbell J. Mcrobbie. "Using Metaphor to Probe Students' Conceptions of Chemistry Learning." International Journal of Science Education, vol. 21, no. 6, 1999, pp. 667-685.

Türkkan, Buket Turhan, and Melis Yeşi $\square$ lpinar Uyar. "The Metaphors of Secondary School Students towards the Concept of Mathematical Problem." Çukurova University Faculty of Education Journal, vol. 45, no. 1, 2016.

Wanjek, Jörg. Einflüsse von Alltagsorientierung und Schülerexperimenten auf den Erfolg von Chemieunterricht. 2000.

Yadigaroğlu, Mustafa, et al. "The Level of PreScience Student Teachers of Relating their Chemistry Knowledge in Daily Life." Ege Eğitim Dergisi, vol. 18, 2017, pp. 795-812.

Yıldırım, Ali, and Hasan Şimşek. Soysal Bilimlerde Nitel Araştırma Yöntemleri. Seçkin Yayınc1lık, 2011.

Yıldızlı, Hülya, et al. "A Meta-Synthesis on Turkish Metaphor Studies of Teachers." Education and Science, vol. 43, 2018, pp. 1-43.

Zoller, Uri. "Students' Misunderstandings and Misconceptions in College Freshman Chemistry (General and Organic)." Journal of Research in Science Teaching, vol. 27, no. $10,1990$.

\section{Author Details}

Mustafa Yadigaroğlu, Aksaray University,Turkey,Email ID: mustafayadigaroglu@hotmail.com 